\title{
CONGRESSIONAL SUPERVISION OF INTERSTATE COMPACTS
}

In 1960, the Port of New York Authority announced plans to build a jetport in New Jersey. ${ }^{1}$ Spurred by objections from residents, a House Judiciary Subcommittee began investigating ${ }^{2}$ charges that the proposal overstepped the Port Authority's power. ${ }^{3}$ Since the Authority had been created by an interstate compact requiring congressional approval, the subcommittee thought Congress had ample jurisdiction to investigate. ${ }^{4}$ The Authority disagreed. Refusing to answer a subpoena," Executive Director Austin Tobin argued that Congress could scrutinize compacts only before it approved them..$^{\circ}$ Congress, he reasoned, had no legitimate concern with the Port Authority's operations once the compact had been approved.

The Port Authority's extraordinary claim-that it was immune from direct congressional control-had the support of several scholars ${ }^{7}$ and a Senate committee. ${ }^{8}$ But the claim was never tested. After the Port Authority director was convicted of contempt of Congress, ${ }^{0}$ the

1. See United States v. Tobin, 195 F. Supp. 588, 595 (D.D.C. 1961), rev'd, 306 F.2d 270 (D.C. Cir. 1962), cert. denied, 371 U.S. 902 (1962).

2. The House Judiciary Committee is charged by Congress with the duty of writing and reviewing legislation concerned with interstate compacts. Congressmen Celler proposed H.R.J. Res. 615, 86th Cong., $2 \mathrm{~d}$ Sess. (1960) requiring (1) that Congress approve in advance any legislation by two states amending or supplementing existing compacts, (2) that reports made to the states by compact authorities also be made to Congress, and ( 3 ) that Congress have the right to see any "relevant" information and to view any authority facility. See United States v. Tobin, 195 F. Supp. at 595.

3. Inquiry Before Subcommittee No. 5 of the House Committee on the Judiciary on the Return of Subpoenas, Port of New York Authority, 86th Cong., 2d Sess., scr. 20, at 15 (1960) [hereinafter cited as Subcommittee Subpoena Inquiry]. See United States v. Tobin, 195 F. Supp. at 594.

4. See Subcommittee Subpoena Inquiry.

5. The records which the subcommitte sought concerned the internal managing, financing and decisional processes of the Authority. Celler, Congress, Compacts, and Inter. state Authorities, 26 LAW \& ConTEMr. ProB. 682, 696 n.103 (1961).

6. Subcommittee Subpoena Inquiry 16-19.

7. See Note, 31 Fordham L. Rev. 581 (1963); Note, 17 N.Y.U. INTR. L. Rev. 95 (1962); Note, 8 Vil.. L. REv. 237 (1963); Note, 70 Yale L.J. 812 (1961). But see Fitederick 1. Zimmermann \& Mitchell Wendell, The Interstate Compact Since 1925, 64 (1951).

8. S. REP. No. 1367, 85th Cong., 2d Sess. 2, 18-19 (1958).

9. H. Res. 530, 86th Cong., 2d Sess. (1960), amending, H. Res. 27, 86th Cong., 1st Sess. (1960); Hearings Before Subcommittee No. 5 of the House Judiciary Committec, 86th Cong., 2d Sess. 20 (1960). In support of Tobin's position, twenty-one states filed an amicus bricf, 
Court of Appeals reversed ${ }^{10}$ on technical grounds ${ }^{11}$ to avoid the constitutional question ${ }^{12}$ and the jetport plan was shelved.13 The answer must be found in an examination of the Compacts Clause, in both its original setting and its modern context.14

The Constitution permits states, with congressional approval, to form compacts in order to solve common problems. ${ }^{15}$ In colonial times and throughout the nineteenth century, compacts were used to fix boundaries and attack small-scale problems through cooperative action. The subject matter was usually of little national importance, and once compacts had been ratified Congress seldom attempted to oversee their operation. During this period the Supreme Court, in dicta accompanying compacts cases, denied that Congress had any power to amend or repeal compacts it had approved.10

acting through the Attorney General of Florida. United States v. Tobin, 195 F. Supp. at 591-92. The court found that Congress had been exercising continuing controls over the authority for years. The FAA had regulated its airports; the Corps of Engineers, its bridge and tunnel construction; and Congress had granted it substantial sums of money. The court also found all technical requirements for valid congressional investigation and subpoena had been fulfilled. 195 F. Supp. 598-603. The court made extensive use of Braden v. United States, 365 U.S. 431 (1961); Watkins v. United States, 354 U.S. 178 (1957); and United States v. Rumeley, 345 U.S. 4 I (1953), in finding that these requirements had been met.

10. Tobin v. United States, 306 F.2d 270.

11. The ground was that Congress had not authorized as broad an investigation as the subcommittee had attempted. Tobin v. United States, 306 F.2d at 276. Both briefs were well over one hundred pages in length, and in each the issue upon which the case was decided took about five pages. In the District Court, Judge Youngdale gave about three pages of a thirty page opinion to the point. See Brief for Appellec, Brief for Appellant, Tobin v. United States, 306 F.2d 270 (D.C. Cir. 1962). The Court ignored much evidence to the contrary on this point. See Brief for Appellee, pp. 49-53, but see Brief for Appellant, pp. 56-62.

12. A contempt of Congress prosecution is not the most practical method of inducing courts to answer broad questions ... when the answers sought necessarily demand far-reaching constitutional adjudications. To avoid such constitutional holdings is our duty. ... [We] have adopted the policy ... in order to obviate the necessity of passing on serious constitutional questions.

306 F.2d at 274-75. The court noted it could find no clear precedent on the issue of whether Congress had the right to repeal an interstate compact. 306 F.2d at 274. Sce ZIMMIERMIANN \& WENDEII, op. cit. supra note 7 , at $40 \mathrm{n} .171$.

13. Celler, supra note 5 , at 701.

14. This setting must be referred to since the courts have so often been unable to distinguish types of compacts. The district and circuit courts in Tobin, for example, characterized the compact as an "operational agency." 195 F. Supp. at 607; a "non-litigeous method for settlement of ... disputes," 195 F. Supp. at 606; a "bi-state agency." 305 F.2d at 271 ; and an entity restoring to the states their original sovereignty, 306 F.2d at 273.

15. U.S. Const. art. I, § 10, cl. 3.

16. See text accompanying notes 51-55. 
Congressional laissez-faire was a sensible policy toward the innocuous compacts of the nineteenth century. But modern compacts have spawned mammoth independent authorities, ${ }^{17}$ armed with political powers and isolated from political control. Compact agencies are the envy-and often the rival-of elected officials. They have been criticized for flouting local interests and national policy, and for vastly exceeding their proper scope. ${ }^{18}$ But with their independent revenues, multi-state jurisdiction, and freedom from public accountability, only congressional scrutiny can bring them under control.10

While congressional power to control compacts has been debated at length, both sides have neglected the most plausible instrument for congressional control: the enumerated powers. ${ }^{20}$ As instruments

17. These authorities have grown with the growth of all-but-governmentally-unitied multistate areas which are often unable to deal with the complex problems resulting from that growth. See Leach, Interstate Authorities in the United States, 26 LAw \& ConreNr. Proв. 666, 679 (1961), and the reluctance of the federal government to provide solutions to regional problems. See Richard H. LEAch \& Redding S. SugG, THE AdMinisization on INTERSTATE CoMPACTS 214-15 (1959). Examples of such compacts are the Port Authority discussed at text accompanying notes 28.43 infra. See also Interstate Oil \& Gas Compact, 78 Stat. 290 (1959); Gulf States Marine Fisheries Compact, 63 Stat. 70 (1949); Ohio Rivcr Valley Water Sanitation Compact, 54 Stat. 752 (1940). Congress has been so anxious for the states to use the compact device that many times they have legislated consent in advance of state agreement to encourage that agreement. See, e.g., Interstate Compact for Airport Facilities, 73 Stat. 333 (1959), Federal Civil Defense Act of 1950, 64 Stat. 1245, 1249 (1951). Between 1789 and 1900 only twenty-one interstate compacts became effective. LEACI AND Sugg, op. cit. supra, at 6. See also McDougal and Rotival, Tile Case fon Regional Planning with Special Reference to New England 25-52 (1947), defining the New England state as a single interstate region with the same problems, united by history, culture, climate, power, and transportation. There are approximately thirty interstate urban areas in the United States. See United States Bureau of the Gensus, Statistical Abstract of the UNITED States 14-15, 17 (1964).

18. See, e.g., Netherton, Area-Development Authorities: A New Form of Government by Proclamation, 8 VAND. L. REv. 678 (1955).

19. See, e.g., text accompanying notes 64.69 supra.

20. This Note is not concerned with the right of Congress to condition its original approval of a compact upon changes in its wording, etc. Much of what is said will necessarily apply to such compacts and to those to which federal agencies are activc parties; however, the thrust of the argument will be directed at those compacts to which Congress has already given assent and to which the federal government is not a party.

It should also be mentioned that litigation of the issues discussed here generally ought to be avoided if possible, since it will likely cause severe federal-state frictions. Rather, political adjustment ought to be the preferred solution to problems concerning compacts.

Continuous and creative administration is needed; not litigation, necessarily a sporadic process, securing at best merely episodic and mutilatcd settlements, which leave the central problems.... unsolved.

Frankfurter and Landis, The Compact Clause of the Constitution-A Study in Interstatc Adjustments, 34 YALE L. J. 685, 707 (1925). Further, the courts probably lack the time and 
through which state power is exercised across state boundaries, compacts are peculiarly subject to the authority of Congress to guarantee the primacy of federal interests.

\section{The Modern Compact in Perspectve}

The activities of the Port Authority of New York, the largest and most self-willed of the regional agencies, illustrate the potential of the modern compact. ${ }^{21}$ It was created after a half-century of futility, 29 the inevitable product of forty governments' attempts to regulate New York's harbor traffic. ${ }^{23}$ Originally, the Authority was given power to build, operate and coordinate transportation facilities throughout the metropolitan area. ${ }^{24}$ Thanks to liberal construction of the compact, its powers multiplied. The Authority now borrows and issues bonds to raise capital funds. ${ }^{25}$ It budgets its revenues and enters into contracts without legislative approval. It controls its own internal organization and is immune from civil service laws..$^{20}$ It can issue subpoenas and its patrolmen are recognized as police in both New York and New Jersey. ${ }^{27}$ It spends more money than four states, ${ }^{28}$ its debt is greater than that of twenty-one others, ${ }^{20}$ and its assets are larger than all but fifty American industrial firms. ${ }^{30}$ It owns, operates, rents, builds and buys, all on its own recommendation, office buildings, railroad lines, warehouse facilities, and the like. ${ }^{31}$ Operating authority is vested in a single director whose decisions are virtually unreviewable

expertise to settle the underlying issues even if raised. See FrEuxd, ON UNderstandisc THE Suprene Court 77-116 (1949); West Virginia ex rel. Djer v. Sims, 341 U.S. 22, $26-27$ (1951).

21. It is often noted as the first of this sort of independent interstate compact authority. See ZIMMERAIANN \& WeNDELI, op. cit. supra note 7, at 5 .

22. The compact was approved by Congress in H.R.J. Res. 337, 67th Cong., 2d Sess. (1922).

23. This early history is taken from two sources, ERwis W. BARD, THE PORT OF NEw YORK AUTHORTY 7-12 (1942) and Goldstein, An Authority in Action, 26 LAw \& CoNTEsp. Prob. 715, 716 (1961). See also The New York Harbor Case, 47 I.C.C. 643 (1917).

24. BARD, op. cit. supra note 23 , at $40,46-50,54$.

25. Id. at $57,272-80$.

26. Id. at 269, 272-80; 1960 PORT of New York Authority ANN. Rep. 61 (1960).

27. Nichol, The Port of New York Authority, p. 61, 1935 (unpublished manuscript in Yale Law School Library).

28. Compate 1961 Statistical Abstract of the United States 410 wilh 1960 Port of NEW YORK AUTHORITY ANN. REP. 61.

29. Compare 1961 Statistical Anstract of the UNited States 412 with 1960 Port of NEW YORK AUTHORITX ANN. REP. 7, 61.

30. Goldstein, supra note 23, at 715.

31. BARD, op. cit. supra note 23 , at 140-60, 269, 272-80. 
by either state. ${ }^{32}$ The result, ${ }^{33}$ according to many critics, is political irresponsibility:

[The Authority] does not make its decisions to build another tunnel, or to expand an airport instead of investing in mass-transit facilities, in terms of the whole public, or of the interest of the whole area. ... It makes its decisions in terms of ... the auto driver who keeps it going with his tolls, and the bond market. ... [1]ike many another authority, ostensibly "non-political," [it] has developed a politics of its own ... [which] may or may not be responsive to the public interest. ${ }^{34}$

The Port Authority has also found itself in direct conflict with federal policies. The Bureau of Roads, for one, has complained that the Authority's use of toll revenues from bridges and roads for investment in all the Authority's collateral activities contravenes a clear federal policy that once roads have paid for themselves they should be free for all users in interstate commerce. ${ }^{35}$

The Port of New York Authority's proposed $\$ 525$ million World Trade Center for Lower Manhattan illustrates the potential for conflict between compacts and communities. The proposal features two one-hundred-and-ten story office buildings that would be the tallest in the world. ${ }^{36}$ Offices would be occupied by the Authority, and space would be rented out to concerns engaged in world trade. There were

32. Above the Director is a Board of Commissioners whose members are appointed to six-year terms by the Governors of New York and New Jersey. They serve without pay and are predominantly businessmen. Their terms are usually renewed and, for all practical effects, they do little reviewing of the Director's decisions. Resoultions in the minutes of the Board's meetings can be vetoed by either Governor within ten dnys after voted upon by the Commissioners, but within the forty years of the Authority's existence this has happened but once. Board members are usually reappointed and some have served for as long as twenty years. The members have become so unresponsive to state claims on the Authority that they have been subject to criticism by the Governors of the states. $I d$. at $267,269-70,272-80,282-84,289$. N.Y. Times, Jan. 10, 1934, p. 8, col. 1 (city ed.); and Jan. 16, 1935, p. 4, col. 8 (city ed.).

33. The Port Authority is not unique in the power it has attained. The Delaware River Basin Compact, consented to by Congress in 1961, has the potential to develop into an independent authority with the power and scope of the Port of New York Authority. It is charged with the financing, building and operating of water supply, power generation. conservation and recreation facilities in a four-state area in which twenty-one million persons live.

See Frederick L. Zrmamermann \& Mitchell. WendelL, New Horizons on the Delaware (1963) (pamphlet); see also Martin, BirkhEAd, Burkhead \& MUNGer, River BAsin AdMinis. TRATION and the Delaware (1960); Dixon, Constitutional Bases for Regionalism, 93 Geo. WASH. L. REv. 47, 61 (1964); Note, 35 Colum. L. REv. 76, 85-86 (1985).

34. New Strength in City Hall, Fortune, Nov., 1957, p. 156, at 256.

35. Netherton, supra note 18 , at 689.90 .

36. N.Y. Times, Mar. 29, 1965, p. 1, col. 4 (city ed.). 
many objections; businessmen and local residents envisioned a massive relocation and the destruction of the center of New York's electronics industry; ${ }^{37}$ a New York State legislative committee charged that office rental exceeded the scope of the Authority's power; ${ }^{38}$ architecture critics alleged that the Center would disfigure the Lower Manhattan skyline; ${ }^{39}$ the Mayor, the City Council, and citizens' group suggested that the money could be better spent on more pressing city needs, ${ }^{40}$ the City Council President urged that public hearings be held on the Trade Center. ${ }^{41}$ Despite these objections, however, New York City was almost powerless to oppose the Trade Center. The Authority's power to borrow money, issue bonds, condemn land and choose the architectural design was subject to neither federal nor local veto. The City's only power over the Authority was to refuse to issue street closing and utility placement permits for the Trade Center construction.42 Ultimately the conflict between New York City and the Authority, which centered on the payment to be made to the city in lieu of real estate taxes, was resolved; ${ }^{43}$ but the power of the Authority to reshape unilaterally the architectural and economic life of New York City was left unchallenged. This Port Authority is a dramatic illustration of the new uses of the compact device-uses which have rendered the aged dicta on compacts a misleading anachronism.

37. New York's famed "radio row," a conglomeration of much of the city's clectronics retailing and wholesaling industry, was centered in the area the Port of New York Authority condemned. N.Y. Times, Mar. 29, 1965, p. 1, col. 4 (city ed.); and Sept. 11, 1965, p. 15, col. 4 (city ed.).

38. N.Y. Times, Oct. 28, 1965, p. 87, col. 4 (city ed.); and Jan. 31, 1966, p. 29, col. 5 (city ed.).

39. See Notes 30, 31, 36 supra. Some of the severest criticisms of the project were directed at its aesthetic characteristics. To many critics the huge twin towers seem grossly out of scale with other architecture on the Lower West Side of New York. See Harpers, May, 1966, pp. 94-100.

40. N.Y. Times, Apr. 30, 1966, p. 53, col. 3 (city ed.); and May 27, 1966, p. 32, col. 2 (city ed.).

41. One of the most surprising aspects about the entire project was that it was clouded in mystery and confusion simply because it was sprung upon the city as a fully developed plan by the Port Authority. Unlike public agencies, the Authority is under no obligation to make public its plans to the City of New York or its residents. Had such a project been launched by the City it would have been subject to the most intense scrutiny. The consis. tent complaint, by contrast, about the World's Trade Center project was that no one was aware of the nature of the project during the planning phase of development. N.Y. Times, Feb. 2, 1966, p. 38, col. 5 (city ed.); Feb. 16, 1966, p. 43, col. 1 (city cd.); Apr. 20, 1960, p. 30 , col. 1 (city ed.); Apr. 20, 1966, p. 53, col. 3 (city ed.).

42. N.Y. Times, July 13, 1966, p. 1, col. 2 (city ed.).

43. N.Y. Times, May 25, 1966, p. 32, col. 1 (city ed.); June 8, 1966, p. 1, col. 2 (city ed.); July 13, 1966, P. 1, col. 2 (city ed.); and July 14, 1966, p. 20, col. 3 (city ed.). 


\section{The Historical Development of Compacts and Compacts Case Law}

\section{A. Boundary Disputes and Treaty Theory}

The compact was first used to settle state boundary disputes arising in the colonial and post-revolutionary eras. Such disputes between colonies were common, because of vague ${ }^{44}$ and expansive land charters, ${ }^{45}$ and inaccurate surveying. ${ }^{46}$ As populations grew, rival claims became more vexing. ${ }^{47}$

The Constitution, reflecting the colonial difficulties in resolving boundary disputes, provided two means for settlement. The states could either sue one another in the Supreme Court and have it determine their boundary, ${ }^{48}$ or reach their own agreements, subject to congressional approval..$^{49}$

The compact device was based not only on the colonial precedent of a negotiated settlement between the parties, but also on an analogy between treaties and compacts that underlay the early cases. Treaties, according to the influential writings of Hugo Grotius, were binding

44. See, e.g., James T. Adams, The Founding of NEw Engl.and 1665-1667, 216, 227, 920, 328 (1921); Allan Nevins, The American States 547, 578-79 (1924).

45. Rhode Island v. Massachusetts, 37 U.S. (12 Pet.) 657, 660 (1838).

46. Virginia v. Tennessee, 148 U.S. 503, 508-09 (1893).

47. Several methods of settlement developed to cope with these colonial disputes. Onc was direct negotiation and agreement between the parties. See, e.g., REcENTs or TIIE UNIVERSITY OF NEW YORK, REPORT ON THE BOUNDARIES OF NEW YORK $24-25$ (1878); DiCKINSON, American Colonial Government 288-90 (1912); see also Rhode Island v. Massachusctts, supra note 45 , at 663 . The solutions reached were rarely permanent, however, since many states were unwilling to abide by the negotiated agreements. Disputing colonicg, wishing a more permanent settlement, submitted their controversy to the King. Sec, e.g., Virginia v. Tennessee, supra note 46 , at 507 , discussing the original North Carolina-Virginia border controversy. This method, though binding on both parties, was extremely slow, and often the lines drawn on the basis of antique charts and maps bore no rclation to the actual lic of the land. By the time the Revolution precluded recourse to the King, and left the states even more free to abrogate agreements reached by negotiation, eleven of the thirteen states were involved in border disputes. Rhode Island v. Massachusctts, supra note 45, at 723.

48. The problem existed, of course, of enforcing the judgments once made. Comparc Kentucky v. Dennison, 65 U.S. (24 How.) 66 (1861), with South Dakota v. North Carolina, 192 U.S. 286 (1904). See generally Powell, Coercing a State to Pay a Judgment: Virginia v. West Virginia, 17 Micr. L. Rev. 1 (1918); Coleman, The State as Defendant Under the Federal Constitution: The Virginia-West Virginia Debt Controversy, 31 HARv. L. REv. 210 (1917); Long, Enforcement of Judgments Against a State, 4 VA. L. REv. 157 (1916).

49. The meaning of the Compacts Clause, it should be noted, is far from clcar. Scc Frankfurter \& Landis, supra note 20, at 694. See Weinfeld, What Did the Framers of the Federal Constitution Mean by "Agreements or Compacts", 3 U. Cur. L. REv. 453, 461 (1936). See also Rhode Island v. Massachusetts, supra note 45, at 724. The Court stated that to exclude boundary settlements from the subjects falling under "agreement or compact" would be to render the Compacts Clause "a perfect nullity for all practical purposcs." 
on the signatory nations by virtue of natural law. ${ }^{50}$ The authors of the Constitution drew the conclusion that interstate compacts, like treaties, should be forever binding on the parties. By implication, Congress as an outside party had no power to amend or repeal these "inviolable" agreements.

An early illustration of the compact theory is Poole v. Fleeger, in which the Court held that a state could bind itself by compact to disregard its own prior land grant. ${ }^{51}$ The Court observed that the independent states, like nations, had the inherent power to enter into binding treaties. ${ }^{52}$ By authorizing Congress to approve compacts, the

50. See SChIFFer, The Legal CoMmunity of MLANKInd 30-31 (1954); Pufendorf and Vattel, two international law theorists who followed Grotius, were known to the founding fathers. Pufendorf, De Jure Naturae et Gentsum III, IV, I (Camegie Endowment Ed. 1935); Weinfeld, supra note 49, at 458-60. The theory still has adherents. MraNaIr, TuE LAW OF TREATIES 493-94 (1961).

51. Poole v. Fleeger, 36 U.S. (11 Pet) 145 (1837). Wilson v. Mrason was the first case to suggest how the Court would regard boundary compacts. Wilson v. Mason, 5 U.S. (1 Cranch) 28 (1801). See also other early cases dealing with interstate boundary compacts; Burton's Lessee v. Williams, 16 U.S. (3 Wheat) 245 (1818); Holmes v. Jennison, 39 U.S. (14 Pet) 471 (1840).

Wilson involved a conflict over title to real property under Virginis law, which was to govern the dispute according to the terms of the compact at issue. The crucial question was whether the Supreme Court had the right to hear the appeal. Defendant argued the Court had no such right on the grounds that the compact's reference to Virginia law referred to the state's rules of judicial procedure, as well as to the substantive law of real property. Virginia judiciary law made base line state court judgments in ticle disputes nonreviewable; hence, defendant argued, judgments of base line federal courts whose jurisdiction was based only on diversity should not be subject to review either. Chief Justice Marshall rejected this argument with the Court's first employment of the "treaty" model for interstate compacts:

This argument would not appear to be well founded, had Virginia and Kentucky even been, for every purpose, independent nations; because the compact must be [interpreted] as providing for the preservation of titles, not of the tribunals which should decide on those titles.

5 U.S. at 57. Marshall, however, did not end his analysis with this narrow finding. He held that even

If ... the compact between Virginia and Kentucky was ... susceptible of the con. struction contended for, that construction could only be maintained, on the principle, the legislatures of any two states might, by agreement between themselves, annul the constitution of the United States.

Id. at 58 .

Since the Constitution gave the Court and Congress control over appeals, said Mrarshall, no agreement between states could dilute that control. He feared if the states could control "procedural" rights in boundary cases, they could also manipulate those procedures in order to decide the outcome with respect to substantive issues. The states, as a result. would lose faith in the permanency and viability of the compact device. Mrarshall, apparently intent on establishing federal supremacy, also had fears that this would dilute the power of the Court.

52. Poole v. Fleeger, supra note 51, at $\mathbf{1 6 2 .}$ 
states had surrendered pro tanto their prior sovereign rights to enter into treaties. But, said the Court, this congressional power was the "single limitation or restriction" 53 on the states' treaty-making power. ${ }^{64}$ Once Congress gave its consent, the compacting states again stood to each other as independent nations for the purpose of the compact-no further interference, such as congressional amendment or repeal, was authorized by the Constitution. ${ }^{55}$

Although the Court's remarks were dicta, they would have been a perfectly appropriate holding had Congress attempted to repeal a boundary compact. When the nation was formed the states were constantly embroiled in boundary disputes. The boundary compact was an amicable method of settling these disputes; but it could be effective only if the states bound themselves permanently. Had Congress been given the power to amend or repeal, boundary compacts would have been truces, not treaties.

Further, congressional repeal power was not essential to federal supremacy. The federal judiciary remained the final arbiter of the compact's terms. Congress had ample opportunity to review the impact of any state agreement before voting approval, thus assuring that federal interests would be taken into account. As boundaries are static,

53. Ibid.

54. Id. at 163 (Baldwin, J. concurring). Justice Baldwin's concurrence is interesting because he was to speak for the Court in the next important compacts case and becausc he added an argument based on close constitutional construction to support the conclusion Congress had no power to revoke consent to interstate boundary compacts. First, Baldwin noted that article $I, \S 10$, clause 2 , gave Congress, by the use of specific language, a continuing right to regulate state activities.

No state shall, without the consent of Congress, lay imposts or dutics . . . and the net proceeds of all duties and imposts ... shall be for the use of the treasury of the United States, and all such laws shall be subject to the revision and control of the congress.

He concluded, then, that when the very next clause contained no such conditional language,

No state shall, without the consent of congress ... enter into any agrecment or compact with another state,

no conditions were intended to exist. Congress could either give consent or withhold itnothing more. Second, Baldwin observed that clause 2 was based on other Congressional powers--those over commerce, taxation, etc.-whereas clause 3 had no collateral source of authority in the Constitution and hence, he argued, it should be narrowly read:

The subject-matter is not within the jurisdiction of Congress ... . The effect of such consent is, that thenceforth, the compact has the same force as if it had becn made between states who are not confederated, or between the United States and a foreign state ... or as if there had been no restraining provision in the constitution. Id. at 165 .

55. See also Rhode Island v. Massachusetts, supra note 45; Robinson v. Campbell, 16 U.S. (3 Wheat.) 100 (1818). 
it was unlikely that subsequent developments would produce unforeseen injury to federal interests.

But the Court's compact doctrine, aptly suited to an age of border disputes, lingered on while new kinds of interstate agreements developed. The Court continued to speak the language of treaties and restoration of sovereignty, thus leading commentators to suppose that no compact could be repealed by Congress. ${ }^{63}$

\section{B. The Modern Compact}

The use of the interstate compact grew and changed with the nineteenth century, ${ }^{57}$ reflecting the broadened government interest in commerce and economic development. Joint state action, charted in an 1825 compact, led to the construction of the Cheasapeake and Ohio Canal. ${ }^{58}$ The complexity of territorial jurisdiction also provided a new development in compacts; for example, New York and New Jersey agreed in 1833 to permit service of process by either state on the waters of the New York Harbor. 59 Multi-state cooperation also developed in conservation, so that one state would not destroy common resources. Thus, Washington and Oregon agreed to preserve the fish stocks of the Columbia River by compacting not to change their fishing codes without the other state's consent. ${ }^{\text {co }}$

These nineteenth century compacts relied for their effectiveness on conventional state powers, in fields such as process service, conservation, and road building. They used existing state agencies to reach problems of relatively small scope. But even these limited agreements were far removed from boundary compacts. Limited agreements in-

56. See, e.g., Virginia v. West Virginia, 246 U.S. 565, 592-93, 605 (1918); Hinderlider v. La Plate Co., 304 U.S. 92, 106, 107 (1938) (citing Poole v. Flecger, supre note 51 and Rhode Island v. Massachusetts, supra note 45); West Virginia ex rel. Dyer v. Sims, 341 U.S. 22, 32 (1951) (citing Hinderlider v. La Plate Co., supra and Rhode Island v. Massachusetts, supra). See Mora v. Torres, 113 F. Supp. 309 (D.P.R. 1953), af'd sub. nom. Arora v. Arejias, 206 F.2d 377 (Ist Cir. 1953), for an application of this idea to a "compact" between Puerto Rico and the United States.

57. Boundary compacts continued to be executed; however, thcy beame less important. See, e.g., Connecticut and Rhode Island Boundary Agreement of 1887, consented to by Congress, Act of Oct. 12, 1878, 25 Stat. 553 (1888). Interstate compact cases continued to arise also, though by the end of the 19th century they were so well-settled in principle that they consumed little court time. See, e.g., Central R.R. v. Jersey City, 209 U.S. 473 (1903).

58. Act of March 3, 1825, 4 Stat. 101 (1825).

59. Act of June 28, 1834, 4 Stat. 708, 710-11 (1834). Similar pacts were concluded between New Jersey and Delaware, Act of Jan. 24, 1907, 34 Stat. 858 (1907), and Mrississippi and Arkansas, Joint Resolution of Jan. 26, 1909, 35 Stat. 1161 (1909).

60. Act of April 8, 1818, 40 Stat. 515 (1918). Considerable litigation arose out of this compact. Alsos v. Kendall, III Ore. 359, 227 Pac. 286 (1924); see also State v. Gates, 104 Ore. 112, 206 Pac. 863 (1922); State v. Belknap, 104 Wash. 221, 176 Pac 5 (1918). 
volved a continuous interstate relationship, whose full significance probably would not be apparent at the beginning. A dam-building project might turn out to hamper federal developments downstream; a bi-state agricultural agreement could become a hindrance to regional marketing. ${ }^{61}$ Thus the dicta of the early Supreme Court decisions, appropriate to the boundary compacts, became increasingly irrelevant to the impact of the compact on the federal system.

\section{The Independent Authority}

In the twentieth century, neighboring states often encounter problems which demand continuous joint effort. Rather than leave these problems to bilateral negotiation, the states have compacted to establish independent authorities, whose expansive powers and corporate form are designed for operating flexibility. ${ }^{02}$ Typically, the authority's powers include borrowing money and seeling services for profit. To allow for expert planning and to exclude "political" influences, it is freed from the pressures to which legislatures subject ordinary state agencies.

The differences between an "authority" compact and a boundary agreement are apparent. ${ }^{03}$ Instead of neatly solving a dispute, the au-

61. At first it appeared that the courts recognized the changing nature of these compacts when they began to use contract theory in some cases to define the relationships among compacting states.

In one example of this new kind of compacts case, Kentucky v. Indiana, 281 U.S. 163 (1930), the parties had agreed to build a bridge across the Ohio River. Both states began performance, but Indiana reneged when a taxpayers' suit challenged Indiana's participation in the compact as ultra vires. Kentucky sued in the Supreme Court to restrain "breach of contract," and asked for "specific performance." Id. at 169. The Court held that it had the power to interpret the "obligation of contract" problems involved, and decreed performance. Id. at 169. A similar case is South Dakota v. North Carolina, 192 U.S. 286 (1904).

In several early cases the Court had the opportunity to use contract language and reasoning to decide boundary compacts cases. The Court consistently rejected that language and reasoning as inappropriate. See, e.g., Burton v. Williams, 16 U.S. (3 Whcat.) 244, 248 (1818); Virginia v. Tennessee, 148 U.S. 503, 518, 520, 523-24 (1893).

This application of contract theory to explain the new use of the Compacts Clausc may have been partially due to the increasing flow of contracts cases before the Supreme Court, and to the growing national interests in commercial matters. But contract thcory also was an accurate reflection of the nature of the new kind of compact. The states werc joining together for mutual benefit through agreements which established mutual obligations, and under which a variety of relationships were established: joint contributions to build a bridge, or continuing rights to enter on certain lands.

62. See Leach, supra note 17, at 679; ZIMMERMANN \& WENDELL, op. cit. supra note 12.

63. While the independent authority agreements bear a family resemblance to the limited agreement compacts described earlier, there are significant differences. "Contractual agreements" were usually designed to fill a specific gap in state regulation and were conscquently narrow in scope. Such narrowness would destroy the whole purpose of independent authority compacts, which must be as fiexible and broad as the problems they are designed 
thority agreement creates a wealthy and powerful organization which can expand its activities and repulse efforts at political control ${ }^{\text {of }}$ Describing the authority as a new political entity fits the powers held by these authorities: the right to subpoena, investigate, pass regulations, provide enforcement of rules and penalties for breach, raise money, and condemn property. The courts have been accessories to the expansion of authority power. They have, for example, allowed the Port of New York Authority to raise the defense of sovereign immunity to a claim of illegal holding of funds. ${ }^{05}$ In addition, the courts have permitted the authorities to extend their power by making agreements with the states without any congressional approval.06

An interstate authority needs a permissive grant of power to do its job. It could never build a bridge or sail a boat if it constantly had to trek to Congress for approval. But by the same token, the authority's flexibility makes it impossible for Congress to guage in advance the impact of the authority on federal interests. 07

Conflicts between regional authorities and federal interests are

to meet. Where limited agreements use existing state agencies, the authority compact creates new ones, with functions far less restricted than state departments.

64. See, e.g., text accompanying notes 24-43.

65. Howell v. Port of New York Authority, 34 F. Supp. 797 (D.N.J. 1910). For the limits of sovereign immunity, see New York v. United States, 326 U.S. 572 (1910); Note, 66 Harv. L. REv. 898, 904-06 (1953); Hardin, Executive Privilege in the Federal Courts, 71 YALE L.J. 879 (1962). Independent authorities have also been relieved of the burdens of local taxation. Cf. Commissioner v. Shanberg's Estate, 144 F.2d 998 (2d Cir. 19:4), cert. denied, 323 U.S. 792 (1945); Commissioner v. White's Estate, 144 F.2d 1019 (1944); cf. also Graves v. New York ex rel. O'Keefe, 306 U.S. 466 (1939); South Carolina v. United States, 199 U.S. 437 (1905).

66. E.g., in Courtesy Sandwich Shop v. Port of New York Authority, 12 N.Y.2d 379, 190 N.E.2d 402, appeal dismissed, 375 U.S. 78 (1963), the New York Court of Appeals held that the compacting states had the right to expand the power of an independent authority -in this case, to enter the real estate business-without the consent of Congress. The implication of this case is that the states an tailor a compact to any new task which the legislatures may find "necessary and proper," even if it turns the compact into something different from that originally approved by Congress, with no subsequent congressional control. But see Hogue v. Port of Seattle, 54 Wash. 2d 799, 341 P.2d 171 (1959); Opinion of Justices to the Senate, 322 Mass. 769, 126 N.E.2d 795 (1955).

Another issue in Courtesy Sandwich Shop, also held for the Authority, was the right of the Authority to invest in purely income-producing real estate ventures. There have been twenty-six such state additions to Port Authority power in which Congress has not concurred. Brief for Appellant, p. 6, Tobin v. United States, 306 F.2d 270.

The Pennsylvania Supreme Court has gone further than the New York courts in expanding the powers of a compact authority. It held in Fenderson v. Delaware River Joint Toll Bridge Comm'n, 362 Pa. 475, 66 A.2d 843, cart. denied, 338 U.S. 850 (1949), that any one state could broaden the power of a compact within that state's borders without approval either by Congress or the other compacting members.

67. Such criticisms have come from many sources. See, e.g., Dixon, Constitutional Bases for Regionalism: Centralization; Interstate Compacts; Federal Regional Taxation, 33 Gro. WASH. L. REv. 47, 72-78 (1964); Atlantic Monthly, Aug. 1959, p. 38. 
already visible. ${ }^{68}$ Transportation planning, for example is controlled by the Port Authority throughout the New York Metropolitan region. As cities become clogged with automobiles, Congress may want to emphasize mass transportation and to discourage the car-oriented policies of the Port Authority. Alternatively, Congress may decide that authorities have usurped planning and service functions which belong on a local level. Remedial action would almost certainly require amendment or even outright repeal of authority powers which Congress initially approved.

The political irresponsibility of the authorities' regional planners is another potential source of trouble. For years, critics have attacked the philosophy of "objective" regional planning, free from the "taint" of political influence. Congress might decide that there must be a closer relationship between those who plan a community and those who live in it. Such a decision would bring regional authorities squarely within the sights of Congress, since the regional authorities are almost totally divorced from community control. The people do not vote for authority directors or officers, nor have they any direct method of influence.

In none of these cases could Congress safeguard the interests at stake through sophisticated provisos inserted into the compact at the time of approval. Even if Congress were able to foresee jeopardy to federal interests, it could not preclude all conflict without hamstringing the agency. ${ }^{69} \mathrm{~A}$ system of checks and balances might curb political irresponsibility, but it could also make flexible administration impossible. For example, a requirement that capital budget items must be approved by all member states, or that certain kinds of planning decisions be subject to the governors' veto would interfere with business-like management. For Congress to be a judicious supervisor, it must have the

68. See, for an example of some potential and real abuses, Bolger v. Cleary, 293 F.2d 368 (2d Cir. 1961), rev'd, 371 U.S. 392 (1963). Contra, LeAch \& SugG, op. cit. supra note 17, at 222-24. Of course, if possible, interference with compact authorities ought to be avoided. They require some independence and authority to act effectively. See, e.g., BARD, op. cit. supra note 23, at 35-63, 269-80 (1942). However, in some instances, it is felt, these requircments may be overridden. For example, The Missouri-Illinois Bi-State Development Agency was paralyzed between 1953 and 1959 when the two states could not agree upon proper remedial amendments to the compact's powers in order to make it effective in its changing spheres of activity. Other authorities have experienced the same problcms. See Leach, supra note 17, at 671-72; Dixon, supra note 67, at 74, 77.

69. Even when Congress has acted in an attempt to plan for the future the courts have not always helped. An example in which the courts ignored the words of a compact is the Tobin case. There the investigating committee based its investigatory power upon a clause in the Port of New York Authorty compact which gave Congress the power to "alter, amend or repeal." The court, however, ignored that clause and implied that despite its existence Congress had no power to repeal. Tobin v. United States, 306 F.2d 270. 
power to wait until a compact has taken shape, assess the consequences to federal interests, and then, if necessary, act to halt abuse of the compact. The crucial question is whether Congress has this power over the regional authorities, either through the repeal device, or through another mechanism of control.

\section{The Case for Congressional Control}

\section{A. Continuing Federal Interests in Multi-State Compacts}

The application of boundary compact law to independent authorities has led some observers to conclude that Congress has no right to amend or repeal a compact. One author, commenting on the Port Authority agreement, contends:

Thus Congress apparently has only one function with respect to compacts; to screen them before they become operative .... $[T]$ he very consent of Congress rendered the compact irrevocable, since its effect was to remove the constitutional ban against the formation of interstate compacts, thus restoring to the states the inherent sovereignty they enjoyed prior to the Constitution.70

These conclusions, evidently drawn directly from the theories of the boundary agreements, ignore precedent as well as context. The Supreme Court has recognized that the federal interest in a multi-state compact need not end when it is ratified. The Court's acknowledgment of this continuing interest, coupled with the dramatic distinctions between the older compacts and the new, indicates that the doctrinal case against amendment or repeal is far weaker than some commentators have suggested.

Long before the development of independent authority compacts, the Court had suggested that Congress has a continuing interest in any interstate agreement between states which has political repercussions. For example, in Florida v. Georgia, ${ }^{71}$ a dispute over a boundary compact, the United States Attorney General was permitted to intervene against the wishes of both states, to raise issues neither party wanted discussed. The Court permitted the intervention despite the fact that it might have led to a settlement neither state wanted, analogizing the litigation to a compact settlement of a boundary dispute. In the latter instance, said the Court, Congress was given power to approve those interstate agreements where it was necessary for the federal government

70. Note, 31 Fordham L. Rev. 581, 585-86 (1963). See also Note, 8 ViLL. L. Rev. 237, 238 (1963).

71. Florida v. Georgia, 58 U.S. (17 How.) 502 (1854). 
to guard the rights and interests of the other states, and to prevent any compact or agreement between any two states which might affect injuriously the interests of the others. ${ }^{72}$

The Court felt that here the Attorney General should be heard as the guardian of the federal interests.

While this case did not involve a right to amend or repeal, the Court's emphasis on the need to safeguard federal interests is significant. If that is the policy behind Congress' power to review interstate compacts, it would be anomolous to tie Congress' hands in cases where political consequences cannot be assessed at the time of approval. The Supreme Court recognized this political function of congressional power in Virginia $v$. Tennessee, ${ }^{73}$ where it declared that the Compacts Clause applied to agreements which tended to produce an "increase of political power in the states," and which were "attended with permanent inconvenience or public mischief."74 Beyond this, the Court said that Congress could withhold judgment on a compact for several years in order to assess its effects in operation. But if Congress can supervise an agreement simply by delaying final approval, it should be allowed to act promptly and still retain a measure of control. ${ }^{75}$

\footnotetext{
72. Id. at 519 .

73. 148 U.S. 503 (1893).

74. Id. at 519-20.
}

75. Congress can, of course, refuse to approve a compact unless changes arc made. But this is seldom done. See Leach, Federal Government and Interstate Compacts, 29 FondinM L. REv. 421, 429 (1961). Congress cannot, however, require a compact to contain a clause contrary to the Constitution. Note, 73 HARv. L. REv. 1595 (1960). See also Hale, Unconstitutional Conditions and Constitutional Rights, 35 Colum. L. REv. 321 (1935); Merrill, Unconstitutional Conditions, 77 U. PA. L. REv. 879 (1929). This means that Congress cannot require as a condition of approval that the compacting states yield a degree of control to Congress which it is prohibited by the Constitution from having. So the mere fact that Congress specifically puts into compacts a clause retaining for it the right to "alter, amend or repeal," does not give it that right. Leach, stupra at 438.40 . Sec Coyle v. Oklahoma, 221 U.S. 559 (1911).

The Supreme Court, it appears, has made another step toward holding that Congress has effective power to repeal compacts by characterizing independent authority compacts as acts of Congress. In Delaware River Joint Toll Bridge Comm'n v. Colburn, 310 U.S. 119 (1940), the Court considered a New Jersey Supreme Court decision that the Delaware Commission-a "body politic" created by compact with the consent of Congress-was obligated to pay consequential damages in addition to the fair market value of land it took by eminent domain. The first issue before the Court was, however, whether the case could be heard under the certiorari power. The Court wrote

In People $v$. Central Railroad, 12 Wall. 455, jurisdiction of this Court to review a judgment of a state court construing a compact between states was denied on the ground that the Compact was not a statute of the United States. . . This decision has long been doubted ... a and we now conclude that the construction of such a compact sanctioned by Congress ... involves a federal "title, right, privilege or immunity" which ... may be reviewed here on certiorari. . . .

Id. at 427. If this is considered a holding that an independent authority compact is a 


\section{B. Enumerated Powers as a Method of Control}

Whatever the doctrinal confusion over an independent right to amend or repeal, Congress still retains its full enumerated powers. ${ }^{70}$ The Supreme Court has made it clear that congressional assent to a compact in no way estops the Congress from effectively undercutting an agreement through ordinary legislation.

The power of Congress over compacts is illustrated by Pennsylvania v. The Wheeling \& Belmont Bridge Co. ${ }^{77}$ Congress had approved a Virginia-Kentucky compact under which a bridge had been built across the Ohio River. Pennsylvania objected that the bridge as built violated a term of the congressionally-approved compact, under which the river was to remain open for commerce. ${ }^{78}$ The Supreme Court had agreed in a prior case, and ordered the bridge either elevated to permit free flow of commerce or destroyed. In response, Congress passed a bill making the bridge part of an interstate postal road system. The bridge company asked the Supreme Court to reform the original decree, and the Court agreed, ignoring Pennsylvania's claims that the Congress could not constitutionally revise a compact.

The question, said the Court was:

whether or not the compact can operate as a restriction upon the

congressional statute, and given that Congress an repeal its own duly enacted statutes, it would appear Congress has the right to repeal the independent authority compact.

The assertion that Congress retains an interest in compacts after approval is further supported by decisions which suggest that the Congress is the proper branch of government to review authority compacts. For example, in Wolkstein v. Port of New York Authority. 178 F. Supp. 209 (D.N.J. 1959), a New Jersey district court held that Congress was the branch with the principal interest in compacts. Refusing to uphold a bondholder's complaint that Authority activities were beyond its legitimate powers, the court stated first that the Authority was immune from such suit because it was a "political" body performing "governmental functions." However, even had it not been, the court said, the suit was beyond the authority of the judiciary.

In effect the plaintiff is asking a branch of the judicial department of the United

States to decide a purely political question and to intrude, by its judgment, into the domain of legislative discretion which is exclusively delegated to the Congress by the

Constitution. The Court is without authority to accede to plaintiff's request. Such a holding suggests that the Congress has some control over the Authority; for there is little purpose in requiring a citizen to take a complaint to a body without power to remedy that complaint. Id. at 214, 215.

76. Repeal or amendment through the operation of the enumerated powers would, of course, create hardships for the bondholders and others who have relied upon what it had been thought a compact authority would be permitted to do. However, the loss of revenueproducing property and the curtailment of the right to perform certain tasks in certain ways and possibilities investors have always faced whether they bought corporate bonds or municipal ones. The vagaries of economic life can make an investment profitable at one time and unprofitable at another, and the vagaries of political life can make government blessings equally transient.

77. 59 U.S. (18 How.) 421 (1855).

78. Id. at 432 . 
power of congress under the constitution to regulate commerce among the several states? Clearly not. Otherwise congress and two States would possess the power to modify and alter the constitution itself. ${ }^{79}$

The question in issue, of course, did not concern the "alteration of the Constitution," but rather the claim that in approving the terms of the compact, Congress had permanently delegated its right to legislate on interstate commerce relative to the bridge. The answer here was also "clearly not." To hold otherwise would have paralyzed Congress in all fields where a sweeping federal policy might impair a compact's operation in some way. While in this case a third-party state was Congress' antagonist, the reasoning applies equally to compact revisions against the wishes of the compacting states.

The enumerated powers put independent authorities within the scope of congressional power. If, for example, a conservation compact resulted in the destruction of timber preserves, Congress could simply exercise its eminent domain power and take the forest land. Save for the just compensation requirement, ${ }^{80}$ there is no constitutional objection merely because the timber is within the ambit of an interstate compact. Similarly, the commerce power would provide almost certain justification for federal assumption of the Port Authority's duties, were Congress to decide that federal, rather than regional, interests must prevail in the operation of the nation's key harbor area. ${ }^{81}$

79. Id. at 433. For some examples of the breadth of congressional powers under the Commerce Clause see, e.g., Wickard v. Filburn, 317 U.S. 111 (1942); United States v. Darby, 312 U.S. 100 (1941); NLRB v. Jones \& Laughlin Steel Corp., 301 U.S. 1 (1937).

80. There might be, however, some other restrictions upon the use of this power by Congress. See, e.g., the following cases dealing with the Tenth Amendment's limitation on the use of the power: Ashton v. Cameron County Water Improvement Dist. No. 1, 298 U.S. 513 (1936); Indian Motorcycle Co. v. United States, 283 U.S. 570 (1931); Hopkins Federal Savings \& Loan Ass'n v. Cleary, 296 U.S. 315 (1935). Perhaps there are also Duc Process considerations here. See Myers v. United States, 272 U.S. 52 (1926); but see Jamcs v. Dravo Contracting Co., 302 U.S. 134 (1937).

81. The application of this analysis to the Port of New York Authority casc, Tobin $v$. United States, exposes what appears to be a typical misuse by the courts of these precedents. As mentioned earlier, in that case a congressional subcommittec attempted to subpoena the records of the Port of New York Authority. The director of the Authority, Austin Tobin, was cited for contempt when he refused to comply with the subpoena.

The district court, in convicting Tobin for contempt of Congress, wrote that the subcommittee had sought the information to discover if the Port of New York Authority had exceeded the scope of the powers Congress had given it in 1922. United States v. Tobin, 195 F. Supp. at 602 . This statement seems to imply that the subcommittec vicwed Tobin's employer as an independent authority compact, which, since it had become politically irresponsible, might be disciplined. This interpretation is borne out by the facts. The investigation was initiated by New Jersey Congressmen preciscly because the Port Authority had ignored New Jersey interests which it was supposed, in part, to 
Seen in this light, Congress has ample authority to call any interstate agency to account.82 Old case law should not inhibit direct congressional supervision over compacts through the enumerated powers.

represent. The district court apparently concurred in the judgment that the Authority was an independent authority compact which, under the analysis given above, could be repealed or amended by use of the enumerated powers by Congress. The court angued that, since the Authority had an effect on interstate commerce, Congress had the power to repeal the compact upon which it was based in order to regulate commerce. Id. at 605-603. The court's reasoning is weakened, however, because it appealed to boundary compact decisions to support its conclusion about an independent authority compact. Id. at 608. The court appears, then, to have reached the right decision-that independent authority compacts can be repealed-but on a ground which Congress had not unged at the relevant hearing.

The Circuit Court, on the other hand, inclined to the opposite and faulty conclusion: that such compacts cannot be repealed or amended. The court, though conceding that Congress could through independent enumerated congressional powers, reach activities which relate to interstate compacts, balked at holding that repeal or amendment itself was proper. Tobin v. United States, 306 F.2d at 273. This holding, the court wrotc, would be constitutionally impermissible since in giving its consent to the compact Congress restored the states to their "original sovereignty." Further, the court felt interstate boundary compacts were beyond repeal or amendment by Congress. Id. at 273. The Circuit Court, it is believed, improperly used reasons, cases, and the language of treaties, which apply to interstate boundary compacts, to reach a conclusion about independent authority compacts.

At base, the New York Port Authority case was an attempt to bring political responsiveness to an independent authority which, the cases appear to hold, Congress might legitimately repeal or amend with its enumerated powers. From this point of view, it is clear Congress did possess the authority to subpoena the records involved.

82. Three policy objections are generally raised to a congressional power to repeal compacts. First, it is charged that repeal would mean the end of the compacts device, since if a complex and expensive authority might be terminated by a congressional act, states would refuse to invest time, effort, and resources in a compact authority. This objection is substantial, however, only if the congressional power were used indiscriminately, or if Congress decided to eliminate compacts generally. It assumes that the federal government would abandon the techniques of persuasion, negotiation, and conciliation to advance federal interests. Regulation and control of business has not crushed American business; nor have mergers been eliminated by the increasing scope of the antitrut laws. Further, this objection underestimates the vitality of the Amerian politial process. Should Congress define the limits of authority compacts, if regional problems persist, there is no need to fear that the device will fall into disuse.

The second objection to the repeal power is that it will impair federal-state harmony. To say this, however, is to say only that the power might be used where Congres felt that federal policy goals were more important than the frictions resulting from the implementation of that policy. Congress is confronted with conflicting interests each time it legislates. The answer to potentially controversial decisions is not to hold that Congress is to be deprived of a tool of policy-making.

Third, it is alleged that repeal of compacts would lead to political stagnation. If all policies and programs begun by the states must conform to federal standards, diversity and experimentation on the state level will cease. But this again assumes that the existence of a power will automatically produce the extreme exercise of it. Congress presumably will want-to encourage compacts which reflect creative responses to pressing regional needs and will act only where there is an overriding federal interest. It no more follows that a right of repeal will lead to conformity than it does that the congressional right to impeach a President leads to slavish and timid executive action. 